\title{
An essential role of Plasmodium berghei kinesin 8 in axoneme assembly and male gametogenesis
}

\author{
D Depoix ${ }^{1 *}$, S Marques ${ }^{2}$, D Ferguson ${ }^{3}$, T Duguet $^{1}$, T Vucanovic $^{1}$, R Sinden ${ }^{2}$, P Grellier ${ }^{1}$, L Kohl $^{1}$ \\ From Cilia 2014 - Second International Conference \\ Paris, France. 18-21 November 2014
}

\section{Objective}

The male gamete of the Plasmodium parasite is the only developmental stage that possesses a flagellum. Very litthe is known about the identity and function of the proteins involved in the parasite's flagellum assembly. Assembly is intracytoplasmic, IFT independent and extremely fast. To understand this essential step of the parasite life cycle, we focused on a male gametocyte and gamete specific kinesin (Kin8), initially identified by proteomic analysis.

\section{Methods}

Kinesin 8 knock-out parasites were constructed, cloned and their ability to form male gametes in vitro, to fertilize female in vivo and to pursue their life cycle was assessed. The ultrastructure of the male gametocytes/ gametes was studied in detail.

\section{Results}

Kin8 mutant lines produce male and female gametocytes similar to WT parasites but male gametogenesis was severely impaired as male gametocytes were not able to release male gametes (no exflagellation). The ultrastucture analysis revealed a default in axoneme assembly: elongated microtubules were seen in longitudinal sections but the classical 9+2 axoneme structure was never observed. Nevertheless, Kin8 KO mutants were able to form some ookinetes in vivo and could be transmitted by the mosquito to a new host.

\section{Conclusion}

We characterized a kinesin essential for male gametogenesis and axoneme assembly in Plasmodium berghei, providing new insights into Plasmodium flagellar organization.

${ }^{1}$ UMR7245, MNHN, Paris, France

Full list of author information is available at the end of the article
Further characterization and the protein localisation are ongoing.

\section{Authors' details}

'UMR7245, MNHN, Paris, France. ${ }^{2}$ Department of Life Sciences, Imperial College London, London, UK. ${ }^{3}$ Nuffield Department of Clinical Laboratory Science, University of Oxford, Oxford, UK.

Published: 13 July 2015

\section{doi:10.1186/2046-2530-4-S1-P46}

Cite this article as: Depoix et al:: An essential role of Plasmodium berghei kinesin 8 in axoneme assembly and male gametogenesis. Cilia 2015 4(Suppl 1):P46.

\section{Submit your next manuscript to BioMed Central and take full advantage of: \\ - Convenient online submission \\ - Thorough peer review \\ - No space constraints or color figure charges \\ - Immediate publication on acceptance \\ - Inclusion in PubMed, CAS, Scopus and Google Scholar \\ - Research which is freely available for redistribution

